\title{
The Review of Communal Rights on Geographical Indications: Communal Standpoint as Constraints to Legal Protection
}

\author{
Yoan Nursari Simanjuntak* \\ Faculty of Law, University of Surabaya, Surabaya, Indonesia
}

\begin{abstract}
This study analyzed the protection of Geographical Indications on Trademarks and Geographical Indications is regulated in Law Number 20 of 2016. However, as a communal right, Geographical Indications are quite unique. Not only the stages of the process, such as production process, organization, and quality assurance, are quite complex, but also their process requires key conditions, such as, the awareness and the willingness from the local community to protect the local Geographical Indications. When the idea of protecting Geographical Indications is met with resistance from the local community, the communal entitlement to the Geographical Indications needs to be questioned.
\end{abstract}

Keywords: Communal rights, community standpoint, legal protection, geographical indications

Protection of Geographical Indications is intended to protect the potentials of local intellectual property and community welfare. Protection of communal property rights is one of the principles of protection of intellectual property. The social principle which states that the granting of intellectual property rights is not only for the interests of individuals but also for the fulfillment of the communal interests. Any utilisation of economic rights from Geographical Indications will provide additional benefits for all members of the community.

Indonesia consists of 16,056 islands, scattered around the equator at the coordinates of $6^{\circ}$ North Latitude - $11^{\circ}$ 'South Latitude and from $95^{\circ}$ East Longitude - $141^{\circ} 45^{\prime}$ East Longitude, so Indonesia is known as "Zamrud Khatulistiwa". Indonesia's tropical climate brings out a diversity of natural potentials. In addition, Indonesia has more than 400

\footnotetext{
${ }^{*}$ Corresponding author. E-mail: yoan_simanjuntak@yahoo. com.
}

volcanoes, 130 of which are classified as active volcanoes which affect the fertility of the soil. Indonesia consists of 35 provinces and 514 districts / cities. The protection of Geographical Indications in Indonesia on Trademarks and Geographical Indications has been regulated in Law Number 20 of 2016 in 19 articles. The mention of the terminology "Geographical Indications" in the Law cements the efforts as well as the new hope in the protection and promotion of Geographical Indications in Indonesia. The issuance of this law should be appreciated since this is a serious progress from the Government of Indonesia to strengthen and affirm the protection of the potentials of Indonesia's rich and diverse Geographical Indications. This progress is an important pathway to maintain fair business competition, and to provide protection for consumers of Micro, Small and Medium Enterprises, and domestic industries.

The former Trademark Law Number 15 of 2001 is still considered inadequate in accommodating the development of the communal needs related to Geographical Indications. In the Act, the regulation 
on Geographical Indications and Origin Indications is only discoverable in 5 articles. This regulation has been elaborated within the Regulation of Government of Republic of Indonesia Number 51 of 2007 on Geographical Indications.

The number of registered Indonesian Geographical Indications has not been de facto balanced with the real potentials possessed by Indonesia. Indonesia consists of thousands of islands and has a vast territorial area. In addition, the geographical and socio-cultural conditions between regions are very diverse. This condition is going to impact on the variety of products produced between regions. These products are found in the sectors of agriculture, forestry, marine, small industry, and cultural arts.

Geographical Indications is defined as the peculiarities of an item and/or a product due to geographical factors, including natural factors, or human factors, and the influence of both. Geographical Indications indicate certain reputation, quality, and characteristics of the goods and/or products. Potential Geographical Indications in Indonesia should be very large given its unique natural and cultural wealth not shared by other nations and countries in the world.

Yet, only 82 Geographical Indications have been registered. In total, 92 Geographical Indications are of registered status in Indonesia, but 10 of them are from foreign countries. The number of regencies/municipalities should be able to contribute more to the number of currently registered Geographical Indications. As stipulated in Article 70 in Law Number 20 of 2016 on Trademarks and Geographical Indications, the development of Geographical Indications is carried out by the Central Government and/or Local Government. If the 514 regencies/cities in Indonesia had actively implemented these provisions, there would have been a large number of registered potential Indonesian Geographical Indications.

East Java Province as the research site consists of 38 districts/cities, but only 2 East Java Geographical Indications were registered: Java Arabica Coffee Ijen Raung and Sidoarjo Smoked Bandeng. Both of them have obtained a Geographical Indication certificate and with this certificate, East Java was awarded the title of "Intellectual Property Culture Area" by the Ministry of Law and Human Rights of Indonesia on June 9, 2015. East Java Province, based on its topography, can be divided into high, medium, and low plains. These differences in geographical conditions may raise the potentials of diverse Geographical Indications for East Java, many of which have not been explored and properly documented.

The two regions in East Java that are observed in this paper are Mojokerto Regency and Probolinggo Regency. Both regions have the potential for superior Geographical Indications. Mojokerto Regency has an area of about $2.09 \%$ of the area of East Java Province, about $70 \%$ of its territory is plains, consisting of 18 Districts, 299 Villages and 5 Kelurahan. One of the targets in the Mojokerto regency development plan is the growth and development of agribusiness, agro-industry and tourism businesses as well as the active involvement of MSMEs. This is in accordance with the potential of its Geographical Indication, namely cocoa, coffee, cassava, and rice. Meanwhile, Probolinggo Regency is located on the slopes of mountains stretching from West to East along East Java and has the potential for Geographical Indications in the form of mangoes and shallots. Protection of Geographical Indications is very important for both these areas and other areas in East Java and Indonesia. Although there is legal protection for communal intellectual property, it seems that the people do not understand and consider the communal rights they have important to improve their welfare. People's perspective is a very important element and especially for the achievement of the objectives of protection of Geographical Indications. Therefore, it is very important to understand the perspective of society so that the protection of communal intellectual property can be successful.

\section{Geographical Indications}

Section 3 Article 22 - 24 the Agreement on Trade - Related Aspects on Intelectual Property Rights (TRIPs). Article 22 (1) explain Geographical Indications as :

“... indication which identify a good as originating in the territory of a Member, or a region or locally in that territory, where a given quality, representation or other characteristic of the goods is essentially attributable to its geographical origin." 
According to this definition, there are three determining conditions for a product to qualify for Geographical Indications protection. First, the product must be categorized as having either an agricultural or non-agricultural classification; however, there are exceptions to the services that are included in several countries. Second, the geographical origin of the product must be determined. Third, the defined geographical origin can be attributed to the qualities, reputation, and/or other characteristics of the product.

Geographical Indications contained in the norm TRIPs approval is the development of the rules regarding Appellation of Origin as regulated in The Paris Convention for the Protection of Industrial Property 1883 which states:

"... the geographical name of a country, region, or locality, which serves to designate a product originating therein, the quality and characteristic of which are due exclusively or essentially to the geographical environment, including natural and human factor."

At least, there are four main elements of geographic indication in the TRIPs Agreement, namely, first, the geographical name element to identify a product, the name used is not absolute to use the name of origin of the product because it may use a non-geographic name; second, the territorial element in the country as a place of production is not identical with the administrative area but is adjusted to factual conditions. The determination of territory here relates to the area or area as the place or location for goods produced or produced. The criteria used are flexible, that is, they are adjusted to the goods produced; third, the element of ownership in a geographic indication is not an individual right (private right) but a communal right, then a geographical indication is a right to use; and fourth, the quality, reputation, or other characteristics of an alternative nature, so that the goods are sufficient to fulfill one of these elements. ${ }^{1}$

Geographical Indications is part of Intellectual Property Rights which has the basic objective to help meet challenges in development such as reducing poverty, encouraging economic growth. ${ }^{2}$ Intellectual Property Rights is becoming more and more interesting for further discussion because of the current role of Intellectual Property Rights that determines the acceleration rate of national development, especially in the current era of globalization. ${ }^{3}$
Despite the shared economic rationale and legal principles, there are important differences between Indication of Geographical Origins and Trademarks. At a fundamental level there is the difference in terms of what the distinctive sign is signifying. Trademarks are distinctive signs identifying goods of an enterprise and thus not limited by any territorial link. In contrast, 'geography is at the heart' of Indication of Geographical Origins, which in the case of Geographical Indications is a distinctive signs identifying goods with a particular quality as originating from a specific geographical area. Clearly, Indication of Geographical Origins, and Geographical Indications in specific, are not limited to any particular enterprise and thus enjoyed by all enterprises within the demarcated geographical area that qualify for use of the indication. From an economic standpoint, Geographical Indications are seen as a form of collective monopoly right that erects entry barriers on producers either within or outside the relevant geographical area. In sum, Geographical Indications define who can make a particular product, where the product is to be made, and what ingredients and techniques are to be used so as to ensure 'authenticity' and 'origin'. 4

Intellectual property rights are basic rights, human rights for every human being. Article 27 paragraph (2) of the Universal Declaration of Human Rights states that:

"Everyone has the right to the protection of the moral and material intersts resulting from any scientific, literary or artistic production of which he (she) is the author."

Protection of intellectual property is based on the principles:

a. Legal protection warranty: Intellectual property protection will legally declare the real owner of the Intellectual work.

b. Benefits:Intellectual property protection will, in addition, provide benefits, especially for those who implement the protection program, for instance, obtaining royalty payments.

c. Justice:Parties who commit violations towards others' intellectual properties will be subject to legal sanctions.

The function of intellectual property right is basically to protect intellectual property which is the wealth gained from human intellectual ability. This type of right is to value large investments in terms of 
time, energy and cost devoted to produce the intellectual work or invention. ${ }^{5}$

\section{Geographical Indications Regulation in Indonesia}

Indonesian 1945 Constitution, Articles 28, 31, 32, 33 and 34, which emphasises that social justice principles must be inherent in the implementation and management of public resources towards the greatest benefit for the greatest number of people. In this respect, public resources may cover not only natural resources, but also intellectual products which are pivotal components for maintaining and guaranteeing the sustainability of collective life. ${ }^{6}$

The legal aspect of the protection of Geographical Indications in Indonesia is contained in the concept of intellectual property protection as well as in several other rules, such as provisions on unfair business competition and consumer protection laws. In Article 1 Number 6 of Act Number 20 of 2016 on Trademarks and Geographical Indications, Geographical Indications is defined as a sign which indicates the original area of an item and/or a product based on its geographical factors, including natural factors, human factors or a combination of both. Geographical Indications ascribe certain reputation, quality and characteristics to the goods and/or products made. The trademark sign used as a Geographical Indication can be in the form of labels or labels attached to the goods and/or products made. In general, Geographical Indications consist of the name of the product followed with the name of the region or the place indicating the origin of the product. Based on this understanding :

a. The naming of goods/ products should be aligned with the geographical name of a country, or a region.

b. In naming an item or a product, the place of origin, such as a country or a region, should be indicated together with the quality and the characteristics of the goods or products originating from the geographical area.

c. These qualities and characteristics are determined by natural and human factors.

The trademark can be based on the name of a place, an area, or a region. It can also be adopted from a letter, a word, a picture, or a combination of these elements. The definition of the name derived from a place can be taken from the name listed in the geographical map or the name continuously used to indicate the place of origin of the item. Protection of Geographical Indications includes products produced by nature, agricultural goods, handicrafts or other industrial products.

The right to Geographical Indication as an exclusive right of the right holder of Geographical Indication is granted by the State to the registered person, as long as the bases for the protection of the Geographical Indication: the reputation, quality, and characteristics still exist (Article 61 paragraph (1) of Law Number 20 Year 2016 on Trademarks and Geographical Indications). The duration of the protection of Geographical Indications has no time limit when the consistency of the specificity of the Geographical Indications consistency is still registered.

Drawn from the conception of material rights, intellectual property rights are considered objects in Article 499 of the Civil Code. The objects are defined as "every item, and each of those items can be controlled using ownership". Intellectual property rights also known as rights and intellectual property are intangible (Article 503 of the Civil Code), and these rights can be under one's ownership. These rights are also moveable and possess economic values like other valuable objects. The intellectual property rights do not have to be possessed by only one person, and it is shareable with a number of people as joint property rights (medeeigendom).

In contrast to other forms of intellectual properties that are individualistic in nature, the protection of Geographical Indications is collective where the protection is given to a product produced by a particular region. Agricultural products, in particular, should have special qualities derived from production sites influenced by local factors such as climate and soil. The idea of Geographical Indications is not only limited to agricultural products, but also can be used to indicate specific qualities of a product that are strongly influenced by human factors. These human factors can only be found in the place of origin of products, such as certain techniques of product manufacture and tradition.

If a geographical term is used to name a product, yet, not an indication of the place of origin of the product, the term is considered as "generic." This is because that term no longer serves as a geographical indication. "Gudeg Yogya" (originally from Yogya) or "Rendang Padang" (originally from West 
Sumatra) can be easily found in almost every city in Indonesia, but their names do not necessarily function as geographical indications.

According to Emawati Junus, the protection of Geographical Indications provides several following benefits to farmers: ${ }^{7}$

a. increasing the professionalism of farmers (because it requires a specification book to guarantee quality);

b. improve and maintain Geographical Indications products;

c. strengthen farmers 'competitiveness;

d. strengthen farmers' rights through the association of Geographical Indications products;

e. encourage better economic equality for farmers;

f. improve and create employment opportunities for farmers in areas that have the potential for Geographical Indications products.

Geographical Indications are understood by customers to denote the origin and the quality of products, thus GIs are increasingly recognized as a tool for securing consumers' loyalty by establishing the link between product attributes and the geographical origin. ${ }^{8}$ Geographical Indications allow the identification of products with specific quality and characteristics based on geographical factors and distinguishes agricultural product products from other similar products on the market. Geographical Indications will distinguish and protect goodwill or reputation and quality standards of agricultural product and essentially enables agricultural producers to increase profits through product differentiation. A Geographical Indication product would bring in more income than traditional raw commodity exports. Without Geographical Indications to distinguish the products, the high-quality product will be considered undifferentiated one and sold at the same price. ${ }^{9}$

Counterfeiting of Geographical Indications by unauthorised parties is very detrimental to consumers and official producers. Consumers are misled to believe that the 'original' products are of specific qualities and characteristics, but actually receive fake products. At the same time, the producer of the original products suffers huge losses because his valuable business has been corrupted by irresponsible parties, and the reputation the honest producer builds for his product is now tarnished.

The registration of Geographical Indications adheres to a constitutive system, and this means that new protection is given when the registration has been carried out. Registration applies the principle of first come first served. The party who registers their product first obtains the rights to sell the product. Thus, only the first Geographical Indications can be registered within the Directorate General of Intellectual Property to obtain their exclusive rights. The exclusive rights here are the rights to commercialise Geographical Indications so the rightful owner can enjoy the economic benefits. Simultaneously, this has broader implications in the context of international Geographical Indications protection, given that there is no obligation to provide protection for Geographical Indications of unprotected Geographical Indications in their home countries.

The concept of Geographical Indications is based on communal protection. Thus, the process of protecting the Geographical Indications can be implemented by empowering NGOs, government agencies, and local residents to register their unique products as Geographical Indications. ${ }^{10}$ Protection of Geographical Indications is important in business and economic development because :

a. Consumers' right of the genuineness of a product should be protected;

b. Producers are obliged to guarantee that no fraudulent practices occur in the trade practices;

c. Product authenticity and quality assurance are the keys to success in international trade;

d. To develop agrotourism; and

e. Increase the regional income.

Geographical Indications are of unique characteristics in comparison to other forms of intellectual property. They also require the involvement of multiple parties and aspects. New Geographical Indications will be automatically protected once the registration has been received (Article 53 paragraph (1) of Law Number 20 of 2016 on Trademarks and Geographical Indications). Unlike the former regulation in Law Number 15 of 2001 on Trademarks, consumer groups do not serve as parties who can submit registration for Geographical Indications. In Law Number 20 of 2016 on Trademarks and Geographical Indications, Geographical Indications can be registered through the following processes:

a. Institutions which represent communities in certain geographical areas, such as producer 
associations, cooperatives, and the Society for the Protection of Geographical Indications. The institution seeks goods and/or products of the following types:

1) Natural resources, can be used to meet the needs of human life, including not only biotic components, such as animals, plants, and microorganisms, but also abiotic components, such as petroleum, natural gas, various types of metals, water, and soil.

2) Handicrafts;

3) Industrial products: the results of processing raw materials into finished products.

b. Provincial or District/City Government This provision clarifies the arrangement on who the applicant is in the former Act. In the related Act, the applicant consists of the following:

a. An institution that represents the people in the area that produces the goods in question, consists of:

1) A party that seeks goods that are natural or natural products;

2) Producers of agricultural products;

3) Producers of handicrafts or industrial products;

4) A trader who sells the item.

b. Institutions authorised to do so;

c. Consumer goods group;

In the elucidation of the former Trademark Law, Law Number 15 of 2001, the institution representing the community of the research site which produces goods is the institution authorised to register the Geographical Indications. The respective institution is a government institution or other official institutions, such as cooperatives and associations. There is actually an overlap in what is referred to "authorised institution." The regulation in the latter Act mentioned a statement encouraging the Regional Government to carry out and to be responsible for the protection of the superior potentials of a region.

In reality, the existence of this provision does not necessarily provide legal protection for Geographical Indications. One of the fundamental reasons is that regulation regarding the Geographical Indication issues are still prevalent. The core of the problem lies not only within the level of the legal form but also within the substance of the rules used. ${ }^{11}$ There are the two central legal principles that enable Geographical Indications protection : first, Protection against misleading use of a protected indication - a measure aimed primarily at consumers. Second, protection against the dilution of an indication - a measure aimed primarily at the producer.

\section{Communal Rights on Geographical Indications Law in Indonesia}

In the old Law on Trademarks, Law Number 15 Year 200, there are still shortcomings because it has not been able to accommodate the development of community needs in the field of Marks and Geographical Indications. The old law is not sufficient to guarantee the protection of local and national economic potentials, so it needs to be replaced.

Therefore, in the Elucidation section of the new Law (Law Number 20 of 2016, GI is an important part considering Geographical Indications are national potentials that can become superior commodities, both in domestic and international trade. also to protect Micro, Small and Medium Enterprises and domestic industries. This shows that the communal rights of the wider community are of concern and need to be protected. Regional offices of the Ministry of Law and Human Rights with its function as an extension of the Directorate General of Intellectual Property in each province has an important role in the implementation of the dissemination of intellectual property in the regions. To be the spearhead of targeting local communities in a wider scope.

Protection of Geographical Indications is intended to protect the potentials of intellectual property and communal welfare. According to the Regulation of the Minister of Law and Human Rights of the Republic of Indonesia Number 13 of 2017 concerning Data on Communal Intellectual Property. The communal intellectual property is an intellectual property in the form of traditional knowledge, traditional cultural expressions, genetic resources, and potential Geographical Indications (Article 1 Number 1 Permenkumham KIK Data). Intellectual Property whose ownership is group, is different from other types of Intellectual Property whose ownership is exclusive and individual 


\section{Geographical Indications Benefits for Regional Development and Community}

Extending the protection by Geographical Indications would benefit ASEAN countries; Geographical Indications can reinforce the economic fabric in local communities through the presence of additional industries and stimulating quality. ASEAN countries have also acknowledged Geographical Indications in agriculture, food, and handicrafts from which they might profit. Facilitating market differentiation by Geographical Indications for a variety of common commodities such as tea, coffee, and rice that would secure an opportunity for emerging economies to use intellectual property rules which improve their living standards by generating wealth for their communities and preserve their cultural heritage and landscape. ${ }^{12}$

Geographical Indications are frequently regarded as legal instruments to protect, or at least foster, traditional methods and commensurate lifestyles. Within the context of developing countries, local captures of economic value have the capacity to stimulate broader rural development and poverty alleviation. ${ }^{13}$ Geographical Indications are recognized by consumers as valuable products that they will pay more for than standard foodstuffs, and Geographical Indications usually obtain higher prices at the retail level. Producers, the supply chain agents that are more involved in rural development processes, show overall positive but highly variable results that often depend on the specific social, economic and environmental characteristics of the area of production. Positive effects are also emphasized by studies that address the issue from a regional perspective rather than focusing on single groups of actors. Based on the review evidence, we can consider Geographical Indications as a valuable tool to use in an attempt to foster local development processes and to increase agricultural economic sustainability. However, it must be stated that the empirical findings also suggest that the Geographical Indications label does not assure the success of a local initiative alone. Therefore, when deciding to apply for the recognition of a Geographical Indications product, local actors must be aware of the necessity of considering other factors (e.g., cooperation, assistance from institutions, etc.) to achieve the intended results. Nevertheless, from a policy perspective, if the intended objective of providing a useful instrument to be used by local communities in order to enhance their economic performance seems to have been reached, then it is up to these communities to get the best from it. ${ }^{14}$

Geographical indications are understood by consumers to denote the origin and the quality of products. Many of them have acquired valuable reputations which, if not adequately protected, may be misrepresented by dishonest commercial operators. False use of geographical indications by unauthorised parties is detrimental to consumers and legitimate producers. The former are deceived and led into believing to buy a genuine product with specific qualities and characteristics, while they in fact get a worthless imitation. The latter suffer damage because valuable business is taken away from them and the established reputation for their products is damaged

\section{Community Standpoint on Geographical Indications}

Geographical Indication-protected products interact culturally and physically with a community in a specific geographic region, which is a mandatory condition for registration. Geographical Indication products are linked to socio-cultural systems and landscapes that are closely dependent on the socio-institutional and regional Geographical Indication context of the specific rural locality. ${ }^{15}$

In Geographical Indications, natural factors, human factors or a combination of both will affect the reputation, quality and characteristics of a product. Natural factors include, among others, geographic environment, boundaries, climate, soil characteristics, and water availability. Human factors, among others, such as the behavior and habits carried out by humans on the quality and characteristics of goods, process methods derived from local wisdom. ${ }^{16}$ The diversity and condition of human resources, as well as the political will of different local government leaders in each region have an influence on the existence of regional products can be protected by Geographical Indications. ${ }^{17}$

The protection of distinctive signs of localized products, in which Geographical Indications are involved, is based on economic theories of information and reputation. ${ }^{18}$ These theories highlight the importance of: the prevention of market distortion that stems from information 
asymmetry between producers and consumers; minimizing the consequences of such asymmetry through strict regulations on output quality. The Geographical Indications is also considered as the result of a process in which the institutionalization of reputation takes place, which aims to solve certain problems arising from information asymmetry and free-rider on Geographical Indications products' reputations. ${ }^{19}$ In addition to economic benefits, Geographical Indications can also be viewed as a vital contributor to socio-cultural development in rural areas. The profound effects that Geographical Indications have on cultural heritage, particularly the protection and differentiation of localized products, have been evidenced in worldwide research. ${ }^{20}$

The concept of protecting Geographical Indications is derived from the community needs, and the involved community is the owner. The protection of constitutive Geographical Indications requires an advance registration. In addition, communal registration should be done by institutionalised groups. As required in Law Number 20 of 2016 on Trademarks and Geographical Indications, registrants are institutions that represent the community in a particular geographical area, such as among other producer associations, cooperatives, or the Society for the Protection of Geographical Indications that seek goods and/or products in the forms of: natural resources, handicrafts, or industrial products.

Since the community should play a role, the community should first have basic knowledge of Geographical Indications. Knowledge occurs after people see, hear, or apply their own sensibility. ${ }^{21}$ Then, understanding arises, and the community members can start applying the knowledge they have learned. Similarly, knowledge should be first attained, and then applied in terms of Geographical Indications. It was obvious that the community did not fully know what Geographical Indications were. Their knowledge of Intellectual Property Rights, in general, is still limited, and most of it relates only to patents, brands, or copyright. Geographical Indications, though, are completely foreign to the community.

Once the local community fully grasp the basic concept of Geographical Indications, the correct understanding of Geographical Indications, including the importance of protecting Geographical Indications, their benefits, and the communal role can be fully understood. The next stage, application of protection measures for Geographical Indications and community participation, relates to the following factors:

\section{1. a Economic Benefits}

The main consideration for registering the Geographical Indications relates to the economic benefits the community will receive. In Probolinggo that produces quality mangoes, it was found that many mango farmers who no longer planted mangoes had switched to other crops that were more economically promising. This situation is worrisome since the area is critically facing the loss of its potential Geographical Indications. The community does not seem to have the awareness to support regional needs for preservation and development of superior products.

The most dominant consideration in the Geographical Indications relates to profit and loss, as mentioned in Seidman's terminology. Another point was stated by Richard A. Posner, namely the theory of the economics of legal analysis. This theory prioritizes the principle of the usefulness of something / tool. So something must provide benefits / utility values for other esses (social welfare). analysis of economic ideas in developing law includes the transaction costs of economies, economic institutions, and chosen societies. Economic institutions that deal with human action include formal legal rules, informal customs, traditions and social rules. Public choice is concerned with the process of deciding democratically by considering its microeconomic and trade methods. ${ }^{22}$

Cost and benefit calculations primarily serve as the basis for actions. Traders or merchants do not pay careful attention to the quality or the origin of the goods, and the most important thing is "selling goods and obtaining profits." Even though in order to get the profits, the traders lie to the consumers about the origin of the goods. This situation will recur as long as it yields profit. For this group, eliminating their profits is tantamount to protecting Geographical Indications. The public shouldn't have to worry about marketing Geographical Indications products.

The public can use Tregear's thinking to make strategic recommendations for Geographical Indications products: including: product strategy, communication strategy, pricing strategy, and distribution strategy. In product strategy, when considering product identity, it is important to 
ensure that other brand identities - Geographical Indications Label, individual company or retailer label, are consistent with one another. In the communication strategy: Geographical Indications producers should consider establishing a series of message campaigns that highlight the links between their products and local development, environment, etc. It is necessary to develop a separate communication package for distant consumers where images and other symbolic links are being exploited. Pricing strategy: Willingness to pay a premium for Geographical Indication products has been demonstrated in numerous studies; however, the premium level will vary with the product and consumer experience with the product. Distribution strategy: Evidence suggests that Geographical Indication producers have to adopt different distribution channels in different countries. Thus, selling through retailers and supermarkets in countries with highly concentrated supply chains and using local markets, direct selling and specialised outlets in places where they dominate. ${ }^{23}$

\section{2. b Community Culture}

People's attitudes can also be explained from a cultural perspective. People have had a patterned way of life. The existence of the Geographical Indication system requires people to start new ways. Society is not an empty vessel. They have values, norms, and a system of relations as the order that has been implemented so far.

The steps in protecting Geographical Indications are a novelty that differs from previous practical concepts. The newness of the Geographical Indications concept may spur community willingness to change. Yet, conventional farmers may encounter and experience difficulty in implementing the compliance of the farming standards to maintain the unique qualities of the local Geographical Indications. The traders should also be prepared to adopt and to adapt to new practices, such as using new packaging marked with registered Geographical Indications. In the implementation of the Geographical Indications, the community is also obliged to join an institution/association and to be compliant to carry out all procedures along with the consequences of the revoked protection of Geographical Indications when it is no longer implemented. Here, we emphasise the fact that consumers' perceptions of 'origin', 'authenticity' and 'quality' are culturally disparate and differentiated. Consequently, it is important for producers to tap into traditional marketing strategies to convey these factors and enhance the distinctiveness and attractiveness of their products.

\section{3. c Related Party Support}

It is not easy for a community to start a protection program for their local Geographical Indications. For this reason, support from various parties is needed, especially the Government. This is because the registration process of the local Geographical Indications is a lengthy one. This process may involve the following steps: institutionalising community groups, preparing a Geographical Indication's Book, and developing and promoting Geographical Indications. Diperlukan kekuatan besar untuk mengubah pola pandang masyarakat, dan itu dapat dengan cara melibatkan perguruan tinggi, NGOs atau organisasi masyarakat lainnya.

Several studies in other regions in Indonesia show that government support is not optimal. ${ }^{24}$ Insufficient knowledge of Geographical Indications and understanding of the importance of their protection is one of the causes. In the concept of autonomous governance, the regional regions must have their own legal frameworks that are available and autonomous. Regional government has the authority to manage its own governance as a manifestation of regional autonomy by paying attention to the principles of democracy, equity, fairness and basic services, improving the level of community empowerment, and empowerment. ${ }^{25}$ The implementation of broader government functions by the regional governments needs to be supported by adequate financial resources. ${ }^{26}$

The influential role of associations in the agricultural sector should be further enhanced. Instead of limiting membership to producers, the government could request mandatory representation from members of the local authority. This would increase the opportunity for discussions between the different stakeholders, paving the way for greater collaboration and networking between the parties. ${ }^{27}$

Such increased awareness of Geographical Indication system is a prerequisite for producers of the individual products to perceive the merits of the registration. Sharing the aims and concepts of Geographical Indication with stakeholders can facilitate innovation in the current Geographical 
Indication scheme to enable informed choices for consumers. ${ }^{28}$ It takes great power to change the perspective of society, and that can involve universities, NGOs or other community organizations.

Communities generally assume that what is cultivated is solely based on the decisions and needs of the community members themselves. Theoretically, this can be explained using the Rational Choice Theory of Coleman. According to this theory, individual action leads to a goal, and the goal is an action determined using value or preference (choice). In its application, this theory requires the proper concept of rational actors who come from an economical background which permits actors to act by maximising their use or desires and needs. ${ }^{29}$ This perspective requires determination and hard work. Tangible evidence of the benefits is essential that the community be motivated and believe that their participation in promoting Geographical Indication products bring prosperity to their members. However, when a community is not interested in committing themselves to preserve their local protected Geographical Indications, the objectives of protecting community rights in Law Number 20 of 2016 have not been fulfilled.

The protection of geographical indications is growingly advocated to support not only economic but also social and environmental sustainability. Indeed, environmental stewardship has frequently been evoked by policy makers and value-chains actors as a justification for protection. ${ }^{30}$ Products whose quality and/or reputation is highly influenced by their geographical origin are usually accompanied by geographical indications. ${ }^{31}$

In view of the country's national development policies, Geographical Indications are usually considered as policy tools to promote sustainable rural development. Despite the increasing importance of Geographical Indications in the agriculture sector and rural development, a gap still exists in the literature on the contribution of Geographical Indications to rural development. ${ }^{32}$ As a public policy instrument, Geographical Indications have potentially positive implications towards the protection of indigenous knowledge and as a means for generating livelihood and income. However, this potential is constrained by a number of factors related to the limitations of Geographical Indications. For example the misappropriation of knowledge, otherwise termed biopiracy, embedded in an indication will not be protected against. As such, Geographical Indications should be considered part of a wider set of policies directed at these aims.

Geographical Indications can be considered a strategy since they can meet different purposes and involve different actors. They can be protection instruments (to consumer and farmer); marketing instrument (emphasizing the uniqueness of a product or service); rural development mechanism (as it can impact the generation and maintenance of employment, income distribution, local identity, etc.); and means of preservation (traditions, savoir-faire and even ingredients). ${ }^{33}$

\section{The Role of Local Government}

Government Obligations in the Preamble of the 1945 Constitution (Preamble to the 1945 Constitution). As is well known, one of the state's obligations in the Preamble to the 1945 Constitution is to protect the entire Indonesian nation and all Indonesian bloodshed and to promote public welfare. This means, even if they are not asked, or if the customary community owners who have the right to economic and moral rights to the protection of a Communal Intellectual Property do not yet understand their rights and/or are not known for certain, the Government or Local Government can take the initiative to provide protection.

Article 9 paragraph (3) of Law Number 23 of 2014 concerning Regional Government determines the existence of government affairs, which are divided between the Central Government and Provincial Governments and Regency/City Regions. This is known as concurrent government affairs. One of the mandatory affairs of the Regional Government is regarding community and village empowerment (Article 12 paragraph (2) letter g).

In providing protection for KIK, the regulation is in line with article 70 juncto article 71 of the Trademark and Geographical Indication Law that fostering and supervising Geographical Indications is carried out by the central government and / or local governments in accordance with their authority.

\section{Conclusion}

Geographical Indications is a communal right, therefore understanding what is the mindset of the 
community is very important as capital for the Government to be able to formulate strategic steps and policies so that the protection of Geographical Indications can be successful and provide benefits for improving the welfare of the community. The public mindset that focuses more on economic benefits is a challenge for local governments to find appropriate solutions according to local cultural conditions. The government's strategic efforts must be able to demonstrate the achievement of measurable benefits in order to encourage the community to voluntarily develop the potential of Geographical Indications. The government also needs communicative and effective ways to mobilize the community. Mobilization of related parties, such as universities and NGOs, to assist local communities and local governments can be a way to accelerate the protection of Geographical Indications.

\section{Endnotes}

${ }^{1}$ Sasongko, W. (2012). "Indikasi Geografis: Rezim HKI Yang Bersifat Sui Generis". Jurnal Media Hukum, 19(1):102.

2 Sharma, D.K. (2014). Intellectual Property and the Need to Protection, Indian J.Sci.Res.

${ }^{3}$ Kasenda, S. (2017). "Perjanjian Lisensi Antara Pemilik Hak Terdaftar Dengan Penerima Lisensi Menurut Undang-Undang Nomor 20 Tahun 2016 Tentang Merek Dan Indikasi Geografis". Lex Privatum, 5(9): 179.

${ }^{4}$ Rangnekar, D., (2004) The Socio-Economics of Geographical Indications, Issue Paper No. 8, UNCTAD-ICTSD Project on IPRs and Sustainable Development, Geneva.

5 Jened, R. (2016). "Konflik Yurisdiksi dan Penegakan Hukum Kekayaan Intelektual dalam Rangka Pasar Tunggal", Legal Platform, Volume 28, Number 2: 2020.

${ }^{6}$ Haq, H.U. (2014). "Creating Appropriate Legal Framework in the Utilization of Intellectual Property Products", Journal of International Commercial Law and Technology Vol.9, No.2: 70.

7 Junus, W., (2007) "Pentingnya Perlindungan Indikasi Geografis Sebagai Bagian dari HKI dan Pelaksanaannya di Indonesia", Directorate General Intellectual Property, Jakarta.

8 Rahmah, Mas. (2018) The Protection of Geographical Indication for Agricultural Development : Challenges for ASEAN. In: International Conference on ASEAN Studies, 20-23 Maret 2018, PPI Spanyol, Madrid.

9 Ngokkuen, C., Grote, U. (2012). "Challenges and opportunities for protecting geographical indications in Thailand". Asia-Pacific Development Journal, 19(2):93-103.

${ }^{10}$ Aulia, M. Z., (2008) Articles of Intellectual Property Rights in Medialink-FH UII (HKI UII), Yogyakarta as taken from Anggraeni, N. (2013) "Perlindungan Terhadap Indikasi Geografis (Produk yang disertai Nama Tempat) dalam Kerangka Hukum Nasional dan Hukum Internasional.
11 Riswandi, B.A., (2006) "Mencari Bentuk dan Substansi Pengaturan Indikasi Geografis".

12 Banerji, M. (2012) Geographical Indications: Which way should ASEAN Go?. Boston College Intellectual Property \& Technology Forum.

${ }^{13}$ Hoang,G. (2020). "The Impact of Geographical Indications on Sustainable Rural Development: A Case Study of the Vietnamese Cao Phong Orange", Basel, Switzerland : Sustainability Journal, MDPI.12 (11): 1

14 Cei, L., Defrancesco, E., Gianluca, S., (2020) "From Geographical Indications to Rural Development: A Review of the Economic Effects of European Union Policy", Sustainability Journal, MDPI: 15 .

15 Tashiro, A., Uchiyama, Y., Kohsaka, R. (2018) “Internal processes of Geographical Indication and their effects: an evaluation framework for geographical indication applicants in Japan", Journal of Ethnic Foods.

${ }^{16}$ Ramli, T.A. (2015) "Langkah-Langkah Penyusunan Buku Persyaratan Sebagai Prasarat Pendaftaran Produk Indikasi Geografis", Jurnal Litigasi, 2015, Vol 16 No $1: 2597$.

17 Lukito, I. (2018). "Peran Pemerintah Daerah dalam Mendorong Potensi Indikasi Geografis (Studi pada Provinsi Kepulauan Riau)", Jurnal Ilmiah Kebijakan Hukum, Vol. 12 No.3:318.

18 Bramley, C., Bienabe, E. (2012) "Developments and considerations around the geographical indications in the developing world" Queen Mary Journal of Intellectual Property

19 Bramley, C.; Biénabe, E.; Kirsten, J. (2009) "The economics of geographical indications: Towards a conceptual framework for geographical indication research in developing countries". Economics of Intellectual Property, WIPO, Geneva.

${ }^{20}$ Niekerk, J.V. (2000) "The use of geographical indications in a collective marketing strategy: The example of the South African wine industry". Bulletin de l'OIV , $73: 340-367$.

21 Notoatmojo (2010) Metodologi Penelitian Kesehatan, Rineka Cipta.

22 Radjagukguk, E. (2011). Filsafat Hukum. Jakarta: Universitas Indonesia.

23 Tregear, A. 2002 (2002) "Work Programme 4 (Link between origin labelled products and consumers and citizens) Final Report", July 2002. DOLPHINS - Concerted Action, Contract QLK5-2000-0593, European Commission.

24 Effida, D.Q., Susilowati, E., Roisah, K. (2015) "Upaya Perlindungan Hukum Indikasi Geografis Terhadap Salak Sidimpuan sebagai Kekayaan Alam Tapanuli Selatan", Law Reform Journal Volume 11, Nomor 2: 188.

25 Supra note 20

${ }^{26}$ Noviades, D. (2013) “Pengelolaan Keuangan Daerah Di Era Otonomi Daerah", Jurnal Imu Hukum, 2013, Vol 4 No $1: 84$.

27 Hoang, G.; Wilson-Evered, E.; Lockstone-Binney, L. (2020) "Leaders influencing innovation: A qualitative study exploring the role of leadership and organizational climate in Vietnamese tourism SMEs". Employee Relations International Journal.

28 Tashiro, A.; Uchiyama, Y.; Kohsaka, R. (2019) "Impact of Geographical Indication schemes on traditional knowledge in changing agricultural landscapes: An empirical analysis from Japan". Journal of Rural Studies $68: 209$.

${ }^{29}$ Ritzer, G, and Goodman, D.J. (2012) Teori Sosiologi Modern, Revised Edition, Yogyakarta: Kreasi Wacana.

30 Marescotti, A. (2020) "Are Protected Geographical Indications Evolving Due to Environmentally Related 
Justifications? An Analysis of Amendments in the Fruit and Vegetable Sector in the European Union", Sustainability Journal, MDPI:15.

${ }^{31}$ Török, A. et.al., (2020) "Factors Influencing Competitiveness in the Global Beer Trade", Sustainability Journal, MDPI:5.

32 Supra note. 16.
33 Medeiros, M.L., Passador, C.S., Passador, J.L., (2016). "Implications of Geographical Indications: A Comprehensive Review of Papers Listed in CAPES' Journal Database", Innovation and Management Review : 325. 


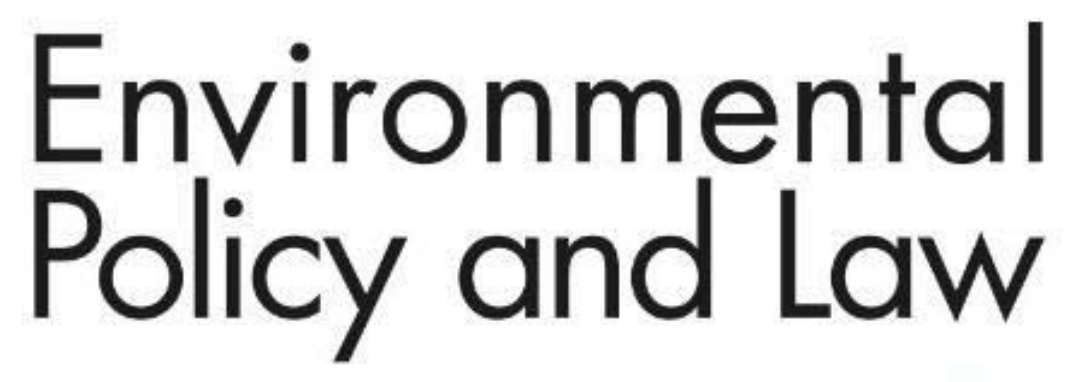

THE JOURNAL FOR DECISION-MAKERS

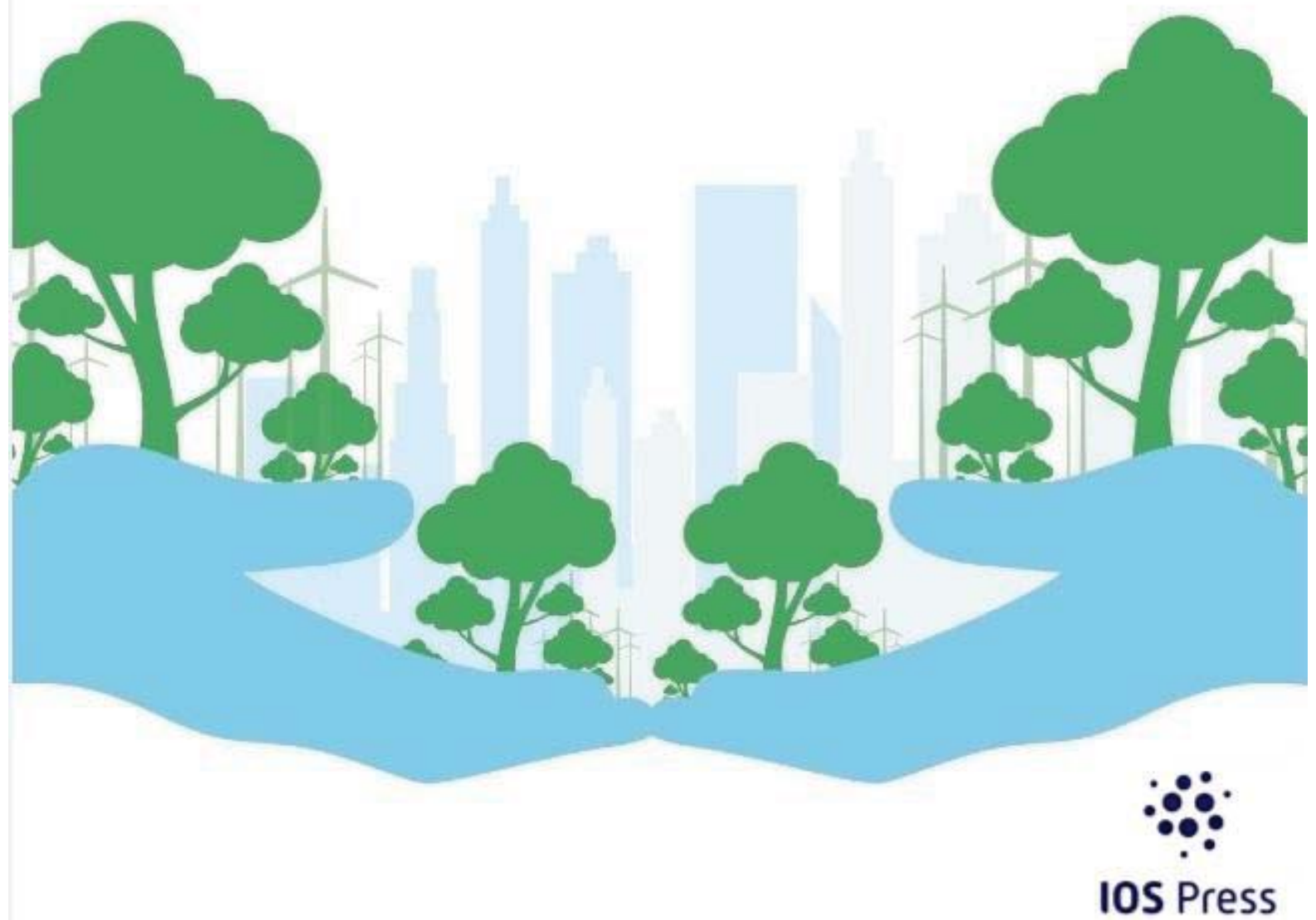




\section{Environmental Policy and Law}

\author{
COUNTRY \\ Netherlands \\ Unversities and research
Institutions in Netherlands
}

Journals

\section{SUBJECT AREA AND CATEGORY}

Environmental Science

Environmental Science

(miscellaneous)

Management, Monitoring, Policy and

Law

Social Sciences

Law

ISSN

0378777X
PUBLISHER

IOS Press

Environmental Policy and Law (EPL) is an international, interdisciplinary journal that facilitates an understanding of environmental policy and law issues not only by drawing upon and contributing to the environmental social sciences, but also linking the health, natural, and computer sciences. The aim of the journal is to promote communication among academia, government, business and industry, and non-governmental organizations who are instrumental in the solving of environmental problems. The journal's scope encompasses a wide range of environmental and natural resource issues, including biodiversity loss, climate change, desertification, environmental pollution and wastes, forest conservation, ozone depletion, renewable and non-renewable natural resources, sustainability, transboundary pollutant flows, and the management of marine and fresh-water resources, and the interaction among these issues. 


\section{submit paper for publication}

How to Publish Paper, free cost publication, ugc care journal policy follow

FIND SIMILAR JOURNALS?

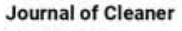

$30 \%$

similarity
2

Sustainable Production and

Consumption

NLD

$29 \%$

similarity

Journal of Environmental Accounting and Management

USA

\section{submit paper for publication}

How to Publish Paper, free cost publication, ugc care journal policy follow

International Journal of Innovation and Sustainable GBR

\section{$25 \%$}

options :

international Journal of Sustainable Engineering GBR

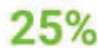

similarity

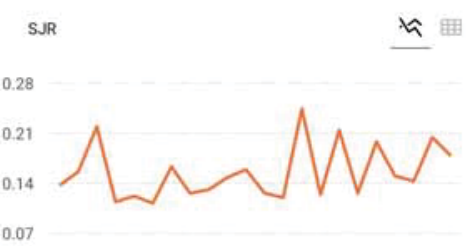

$\begin{array}{llllllll}1999 & 2002 & 2005 & 2008 & 2011 & 2014 & 2017 & 2020\end{array}$

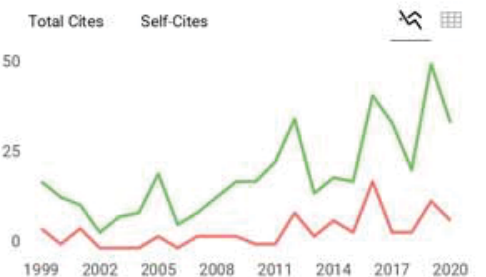

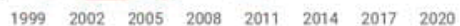

\$ International Collaboration

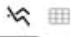

40

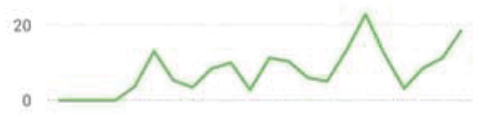

$\begin{array}{llllllll}1999 & 2002 & 2005 & 2008 & 2011 & 2014 & 2017 & 2020\end{array}$

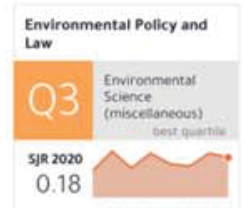

Show this widget in your own website

Just copy the code below and paste within your htm code:

$<$ a href-"https://uww.scim.
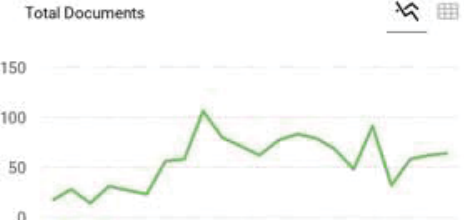

$\begin{array}{llllllll}1999 & 2002 & 2005 & 2008 & 2011 & 2014 & 2017 & 2020\end{array}$

External Cites per Doc Cites per Doc 施

0.4

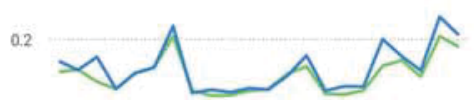

0

$\begin{array}{llllllll}1999 & 2002 & 2005 & 2008 & 2011 & 2014 & 2017 & 2020\end{array}$

Citable documents Noncitable documents in

400

200

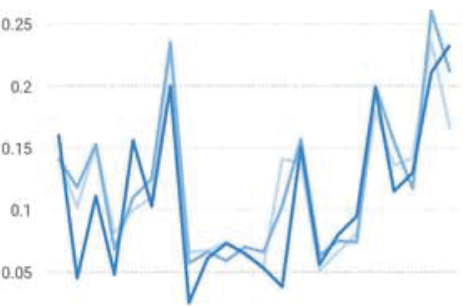

$\begin{array}{llllllll}1999 & 2002 & 2005 & 2008 & 2011 & 2014 & 2017 & 2020\end{array}$

Cites / Doc. (4 years)

Cites / Doc. (3 years)

- Cites / Doc, (2 years)

Cited documents Uncited documents th 再

400

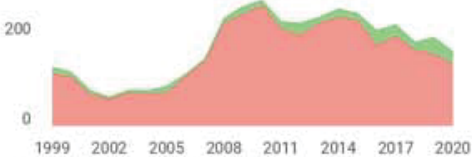

G SCImago Graphica

Explore, visually

communicate and make

sense of data with our new

free tool.

Get it

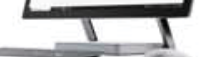


Metrics based on Scopus@ data as of April 2021

I introduce myself, I'm from Indonesia, Bali.

I want to publish my article please help. Thank you.

reply

Melanie Ortiz 4 months ago

Dear Kasta, thank you very much for your comment, we suggest you look for the author's instructions/submission guidelines in the journal's website. Best Regards, SCImago Team

warsit 1 year ago

I am interested in publishing on this jounal

reply

Melanie Ortiz 1 year ago

Dear Warsit, thank you very much for your comment, we suggest you look for author's instructions/submission guidelines in the journal's website. Best Regards, SCImago Team

Hello

I want to publish my research in your magazine, what are the conditions for publishing?

reply

Melanie Ortiz 1 year ago

Dear Andalus,

thank you for contacting us

We are sorry to tell you that SCImago Joumal \& Country Rank is not a journal. SJR is a

portal with scientometric indicators of journals indexed in Elsevier/Scopus.

Unfortunately, we cannot help you with your request, we suggest you visit the journal's

homepage (See submission/author guidelines) or contact the journal's editorial staff , so

they could inform you more deeply.

Best Regards, SCImago Team 


\section{Source details}

\section{Environmental Policy and Law}

Scopus coverage years: from 1975 to Present

Publisher: IOS Press

ISSN: 0378-777X

Subject area: Social Sciences: Law Environmental Science: Environmental Science (miscellaneous)

Environmental Science: Management, Monitoring, Policy and Law

Source type: Journal
View all documents >
Set document alert
$\square$ Save to source list Source Homepage

CiteScore 2020

0.4

(i)

SJR 2020

0.178

(i)

SNIP 2020

0.325

\section{CiteScore CiteScore rank \& trend Scopus content coverage}

i Improved CiteScore methodology

CiteScore 2020 counts the citations received in 2017-2020 to articles, reviews, conference papers, book chapters and data papers published in 2017-2020, and divides this by the number of publications published in 2017-2020. Learn more >
CiteScore
2020
CiteScoreTracker 2021 (i)
$0.4=\frac{71 \text { Citations } 2017-2020}{197 \text { Documents } 2017-2020}$
$0.6=\frac{121 \text { Citations to date }}{201 \text { Documents to date }}$
Calculated on 05 May, 2021
Last updated on 04 November, 2021 • Updated monthly

\section{CiteScore rank 2020 (i)}

\begin{tabular}{lll} 
Category & Rank Percentile & \\
\hline Social Sciences & & \\
$L$ Law & 28th \\
& & \\
Environmental Science & & \\
$L$ Environmental & 13th \\
$\quad$ Science & & \\
(miscellaneous) & &
\end{tabular}

Environmental Science

View CiteScore methodology $>$ CiteScore FAQ $>$ Add CiteScore to your site $\mathbb{C}$ 

About Scopus
What is Scopus
Content coverage
Scopus blog
Scopus API
Privacy matters
日本語に切り替える
切换到简体中文
切換到繁體中文
Русский язык
Help
Contact us
ELSEVIER Terms and conditions $\pi$ Privacy policy $\pi$

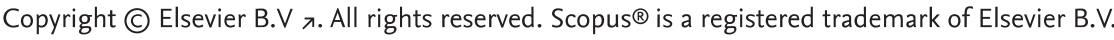
We use cookies to help provide and enhance our service and tailor content. By continuing, you agree to the use
Q RELX
of cookies. 


\section{Editorial Board}

Home" Editorlal Bosrd

\section{Editor-in-Chief}

Bharat H. Desal, PhD

Jawaharlal Nehnu University, Centre for International Legal Studles, New Delnl, Indla

Emalt: desalQjun.ac.in

\section{Publisher}

Marten stavenga

IOS Pre6s, Amsterdam, NL

Enalt: m. stavenga Q iospress.ni

\section{Emeritus Editors}

Founding Editor

Woltgang $E$. Burnennet

Honorary Editor

Achilm Stelner

Former Editor

Marlene Jahnve

Associate Editors

Ellsa Morgera, PhD - Univershy of Strathclyde Law School, Glasgow, UK Melanle Jean Murcott, LLD - Unlversity of Pretorla, Department of Publlc Law, Preforla, South Atrica Vaiters Nsoh, PhD - Birmingham Law School, Universiny of Blrmingham, Birmingham, UK

Tilna Paloniltty, LLD - Univershy of Helsinkl, Helsinkl insthute of Sustainability Sclence and Faculty of LaW, Helsinkl, Finland David C. Smith, PhD - The University of the West Indles, Insthute for Sustainable Development, Kingston, Jamalca 


\section{Editorial Board}

Yann Agulla, Affillate Professor - Sclences Po, Paris, France

Ioannis Athanasladlis, PhD - Wagenlngen Universiny, Department of Environmental Sclences, Wageningen, $\mathrm{NL}$

Iiker K. Basaran, PhD - Teras A\&M Universiti, Galveston, TX, USA

Antonlo Herman BenJamin, PhD - National Hilgh Court, Brasilla, Brazll

Benjamin Boer, LLM - The Univershy of Sjoney Law School, Sjoney. Australla

Klaus Bossaimann, PhD - Univershty of Auckland, New Zealand Centre for Environmental Law. Auckland, New Zealand

Edith Brown Valss, PhD - Georgetown Univershy, Georgetown Law, Washington, DC, USA

Phillppe Cullot, JSD - SOAS Univershy of London, School of Law, London, Untied Kingdom, and Centre for Pollicy Research, New Delnl, indla

David Frestone, LLD - George Washington Universht, Law School, Washington, DC, USA

Eeva Furman, PhD - Finnlsh Enironment insthute SYKE, Environmental Pollcy Centre, Helsinkl, Finland

Camena Guneratne, PhD - Open University of Srl Lanka, Department of Legal Studles, Srl Lanka, Srl Lanka

Alyjandro Iza, LLD - IUCN Endronmental Law Programme, Enironmental Law Centre, Bonn, Germany

Jordil Jarla-Manzano, PhD - Fovira I Virgill Univershy, Tarragona Centre for EnMironmental Law Studles, Tarragona, Spain

Kirk VL. Junker, PhD - Universiny of Cologne, Faculty of Law, Cologne, Germany

Michelle Lim, PhD - Macquarle Universihy, Macquarle Law School, Sjonej. Australla

Sald Mahmoudl, LLD - Stockhoim Univershi, Faculty of Law, Stockhoim, Sweden

Nel9 Matz-LUck, PhD - Klel Univershy, Walmer SchDoking insthute for International Law, Klel, Germany

Owen Mcintyre, PhD - Univershy College Cork, School of Law \& Environmental Research insthute, Cork, Ireland

Kazuhliro Nakatanl, LLB - University of Tokjo, Faculty of LaW, Tokjo, Japan

Ann Powers, JD - Pace University, Pace Law School, New York, NY, USA

Vaiter Rademacher, PhD - Saplenza University of Fome, Department of Statlistical Sclences, Rome, italj

Eckard Rehbinder, LLD - Goethe Universht, EnIronmental Law Research insthde, Frankturt, Germany

Benjamin J. Richardson, PhD - Unlversthy of Tasmanla, Faculty of LaW, Hobart, Australla

Nicholas Robinson, JD - Pace Universiny, Pace Law School, New York, NY, USA

Ollver C. Ruppel, LLD - Stellenbosch Univershy, Faculty of Law, Stellenbosch, South Atrica, and University of Graz, Research Center for Cllmate Law [CllmLaW] at the

Faculty of Law, Graz, Austria

surja P. subedl, QC, DCL - University of Leeds, School of Law, Leeds, United KIngoom

Cleo VerkulJl, LLM - Stockhoim Enironment Instute, SEI Oxford, Oxtord, UK

Christina Volgt, JD - University of Oslo, Degartment of Publlc and International Law, Oslo, Norwaj

Tomme Rosanne Young. JD - Hastings College of the Law, Univershy of Callomla at San Franclsco, San Franclsco, CA, USA

\section{Website Editor}

Carmal McNamara, PhD

OS Pre65, Amsterdam, NL

Emalt: c.mcnamaraQQiospress.nl 


\section{Environmental Policy and Law - Volume 51, issue 5}

Purchase individual online access for 1 year to this journal. Price: EUR 150.00 A Add to cart

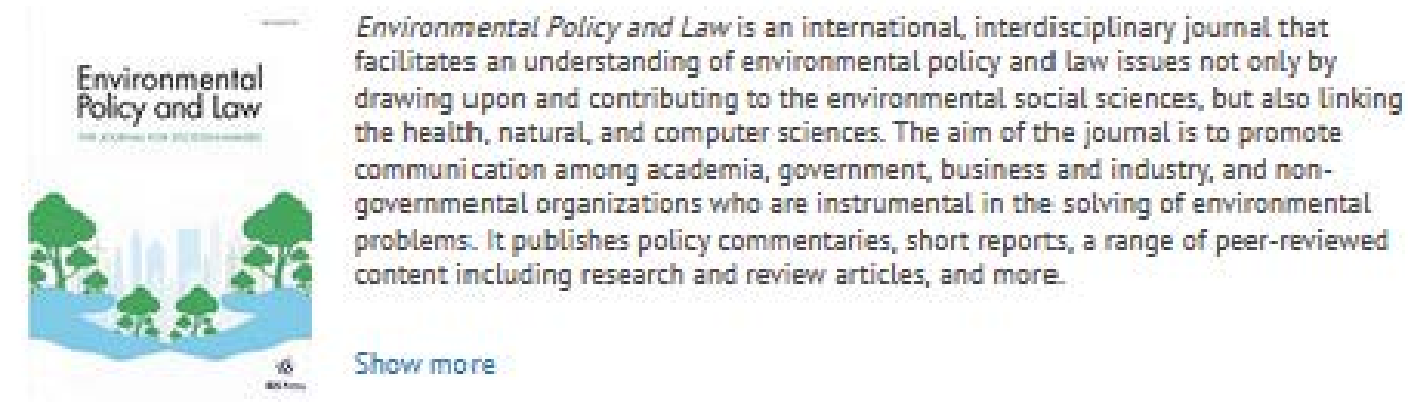

ISSN 0378-777X (P)

ISSN $1878-5395$ (E)

Mark all Add marked to cart Export marked citations

Preface (Volume 51, Issue 5)

Authors: Desai, Bharat $\mathrm{H}$.

Article Type: Other

DOI: $10.3233 /$ EPL-219014

Gitation: Environmental Policy and Law, vol. 51, no. 5, pp. 271-272, 2021

\pm Get PDF

\section{A Regional Review of Genetic Resource Access and Benefit Sharing - Key Issues and Research Gaps}

Authors: Morrison, Clare | Humphries, Fran | Lawson, Charles

Article Type: Research Article

Abstract: Countries are increasingly using access and benefit sharing (ABS) as a legal mechanism to support the conservation and sustainable use of the world's biological diversity. ABS regulates collection and/or use of genetic resources/traditional knowledge and sharing benefits from their use with the provider. The purpose of this review is to assess the trends, biases and gaps of ABS literature using a regional comparative approach about the key topics of concern between each region. It analyses four key topic groupings: (1) implementation of international, regional and national ABS policy and law; (2) intellectual property and ABS; (3) traditional knowledge; and (4) ... Show more

Keywords: Access and benefit sharing, convention on biological diversity, traditional knowledge, biodiversity

DOI: $10.3233 / E P L-201028$

Gitation: Environmental Policy and Law, vol. 51, no. 5. pp. 273-296, 2021

4. Get PDF 
The Review of Communal Rights on Geographical Indications: Communal Standpoint as Constraints to Legal Protection

Authors: Simanjuntak, Yoan Nursari

Article Type: Research Article

Abstract: This study analyzed the protection of Geographical Indications on Trademarks and. Geographical Indications is regulated in Law Number 20 of 2016 . However, as a communal right, Geographical Indications are quite unique. Not only the stages of the process, such as production process, organization, and quality assurance, are quite complex, but also their process requires key conditions, such as, the awareness and the willingness from the local community to protect the local Geographical Indications. When the idea of protecting Geographical Indications is met with resistance from the local community, the communal entitlement to the Geographical indications needs to be questioned.

Keywords: Communal rights, community standpoint, legal protection, geographical indications DOL: $10.3233 /$ EPL-210001

Citation: Environmental Policy and Law, vol. 51, no. 5, pp. 297-308, 2021

Price: EUR 27.50 F Add to cart

\section{Rent Soil Theory Versus Sustainable Development Goals in Indonesia: Environment Law Perspective}

Authors: Hananto, Pulung Widhi Hari I Trihastuti, Nanik I Muhammad Rizk, Dzulfiki I Bismono. Ramadhan Catur

Article Type: Research Article

Abstract: Indonesia is known as a rich country with its forests and various biodiversity. In regard to the issue of forest use and management in Indonesia, there are always pros and cons in how to manage the forest properly. To support the economic sector in Indonesia, the government atways optimizes forest functions and clearing forests for the business sector. In practice, Indonesia implements soilrent theory, which triggers polemics because there is friction with sustainable development goals (SDG). This article is using normative research method. Later on, this article will discuss the gap between the rent soil theory and sustainable development goals _ Show more

Keywords: Rent-soit theory, sustainable developments goals (SDGs), environment law

DOI: $10.3233 /$ EPL-201046

Gitation: Environmental Policy and Law, vol. 51, no. 5, pp. 309-315, 2021

Price: EUR 27.50

F. Add to cart

\section{Making the Case for Reforms of Forestry Policy and Law: Lessons and Experiences from Nigeria}

Authors: Fajemitokun, Bola

Article Type: Research Article

Abstract: The 2030 Agenda for Sustainable Development incorporates 17 Sustainable Development Goals (SDG5). Goal 15 (SDG 15) focuses on terrestrial ecosystems. Regarding forests, it sets targets requiring signatories to promote the implementation of the sustainable management of all types of forests by 2020 and further mobilize significant, rescurces from all sources to achieve sustainable forest management. The United Nations Strategic Plan for Forests 2017 - 2030 advances the vision of SDG 15. Nigeria's high demographic growth rate has led to the surging demand for land to support settlements and farming. Coupled with extensive illegal or uncontrolled logging, the annual forest net - Show more

Keywords: Nigeria, sustainable development goals (SDGs), SDG 15, sustainable forest management: forestry policy, forestry law

DOI: $10.3233 /$ EPL-201004

Gitation: Environmental Policy and Law, vol. 51, no. 5, pp. 317-325, 2021

Price: EUR 27.50 
The Responsibility of the Indonesian Government to Fulfill the Rights to Water During the COVID-19 Pandemic: Some Legal Issues

Authors: Astriani, Nadia | Rubiati, Betty | Adharani, Yulinda | Afifah, Siti Sarah | Salsabita, Rewita | Diffa, Rizkia

Article Type: Research Article

Abstract Indonesia has enough access to freshwater resources of the planet. Hovever, uneven distribution together with mediocre water management and a lack of water infrastructures make a significant number of households in this country have inadequate access to safe water. This becomes big issues, because the provision of safe water, sanitation and hygienic conditions are essential to protect human health and save humanity during the Covid-19 pandemic. When this article was written, COVID-19 patients who were confirmed to be infected were in all indonesian provinces, with the largest numbers of patients located in Java. The purpose of this study is to _. Show more

Keywords: Indonesia, clean water, COVID-19

DOI: 10.3233 /EPL-201044

Citation: Environmental Policy and Law, vol. 51, no. 5, pp. 327-341, 2021

4 Get PDF

$\square$ Integrating Environmental Requirements into Vietnamese Sectoral Laws: Some Legal Issues

Authors: Dung, Mai Thanh | Khoa, Nguyen Minh | Thi Thu Huong, Phan

Article Type: Research Article

Abstract The need for sustainable development underscores the role and importance of integrating environmental concerns in non-environmental policies because it is evident that environmental regulations only are insufficient to manage all environmental issues. Law enforcement on environmental protection in Vietnam clearly demonstrates this situation. Vietnam's legal system of environmental protection is incompatible or overlapped with other sectoral laws and in fact many environmental matters have been implemented in accordance with sectoral laws while disregarding environmental conisiderations due to the lack of specific and explicit environmental provisions or requirements in sectoral laws and regulations. From that situation, the paper emphasizes the need Show more

Keywords: Integrating environmental protection requirements, sectoral legal systems, environmental policy integration, sustainable development

DOL: $10.3233 /$ EPL-201010

Citation: Environmental Policy and Law, vol. 51, no. 5, pp. 343-350, 2021

Price: EUR 27.50

F Add to cart

\section{Active Pharmaceutical Ingredients (APIs) in Malaysian Tap Water: A Gite Way Forward for Upcoming Legislative Framework}

Authors: Othman, Adilleh I Ariffin, Mariani | Johari, Wan Lutfi Wan

Article Type: Research Article

Abstract: Active Pharmaceutical Ingredients (APIs) are the ingredients in pharmaceutical, personal care products, and agriculture that are biologically active, causing detrimental effects to humans and the environment. The detection of pharmaceutical contaminants in Malaysian rivers suggests a high risk for the contaminants to reach tap water since the river is the primary source of water intake points for all drinking water treatment plants and the inability of these plants to treat emerging pollutants like the APIs, in response to the issue, this study aims to evaluate selected documents on the characteristics and properties of pharmaceutical contaminants that are harmful and examine .Show more

Keywords: Malaysia law, pharmaceutical residue, medical waste, clinical waste, multi-barrier approach DOI: $10.3233 /$ EPL-201041

Citation: Environmental Policy and Law, vol. 51, no. 5, pp. 351-358, 2021 